\title{
Dilema sosial: Representasi sosial tentang pajak pada Aparatur Sipil Negara
}

\author{
Ika Rahma Susilawati ${ }^{1,2 *}$ \& Rahmat Hidayat ${ }^{2}$ \\ ${ }_{1}^{1}$ Program Studi Psikologi, Fakultas Ilmu Sosial dan Ilmu Politik, Universitas Brawijaya, Malang \\ ${ }^{2}$ Fakultas Psikologi, Universitas Gadjah Mada, Yogyakarta
}

\begin{abstract}
Abstrak
Penelitian ini bertujuan untuk mengetahui dan mengulas gambaran representasi sosial tentang pajak pada kelompok masyarakat dengan jenis pekerjaan Aparatur Sipil Negara (ASN). Pada studi-studi sebelumnya, tema negatif lebih sering muncul. Penelitian ini berupaya untuk memahami lebih lanjut representasi sosial tentang pajak pada populasi khusus, yaitu ASN dengan secara khusus melibatkan 200 ASN Pemerintah Kota di Provinsi Jawa Timur sebagai partisipan. Data diolah dengan analisis konten - skema koding per kata. Hasil menunjukkan bahwa representasi sosial tentang pajak tertinggi adalah tema positif. Lebih jauh lagi, kami juga menemukan tema lain yaitu netral-teknikal, dan negatif. Tema positif yang dominan muncul bisa dikaitkan dengan budaya kerja ASN. Oleh karena itu, pada bagian diskusi kami menjelaskan temuan ini dengan pendekatan persepsi keadilan sosial, pertukaran sosial antara relasi individu-pemerintah, nilai moral patriotisme, serta rasa kewajiban (sense of duty).
\end{abstract}

Kata kunci: pajak, patriotisme, pertukaran sosial, rasa kewajiban, representasi sosial

\begin{abstract}
This study aims to explore the social representation of taxes among civil servants. Previous studies found that representation of taxes are more likely to be negative themes. This study seeks to further understand the social representation of tax among civil servants by specifically involving 200 employees of the local government in East Java Province as participants. We found that the highest percentage of the social representation of tax was a positive theme. Furthermore, we also found neutral-technical and negative themes even though this is not the major representation. Positive themes that are dominant can be traced to the civil servants work culture. Therefore, in the discussion, we explain these findings by the approach of perceived of social justice, social exchange of individual-government relations, the patriotism and a sense of duty.
\end{abstract}

Keywords: patriotism, sense of duty, social exchange, social representation, tax

\section{Pendahuluan}

Bagi pemerintah Indonesia, pajak menjadi sumber utama pendapatan negara yang menopang pembiayaan berbagai kegiatan pembangunan nasional (Direktorat Penyusunan APBN \& Direktorat Jenderal Anggaran, 2019). Begitu pentingnya sumbangan dari sektor pajak, Direktorat Jenderal Pajak di bawah Kementerian Keuangan Republik Indonesia berusaha mendorong optimalisasi pendapatan pajak melalui berbagai langkah peningkatan kepatuhan pajak pada masyarakat (Direktorat Jenderal Pajak, 2016; Oktara, 2017). Berbagai kajian tentang kepatuhan pajak dilakukan umumnya dari perspektif ilmu ekonomi atau ekonomi publik. Perspektif ekonomi selama ini berpijak pada formalisme matematis dan memandang individu sebagai homo economicus yang memandang perilaku didasari atas pemikiran rasional dan prinsip ekonomi semata (Lewis, 2008). Persoalan pajak juga seringkali dilihat hanya dari perspektif yang lebih makro seperti sistem operasional, teknologi, regulasi ekonomi, desain pajak dan sebainya (Ameyaw, Oppong, Aba Abruquah, \& Ashalley, 2016; Daude \& Melguizo, 2010; Griffith, O'Connell, \& Smith, 2019; Huseynov \& Klamm, 2012; Sutinen \& Kuperan, 1999). Di lain sisi, penting pula membahas perilaku kepatuhan dari sudut pandang perilaku atau ilmu psikologi. Hal ini bermanfaat untuk membantu memahami dinamika psikologis yang tidak tampak (non-observable) namun mampu memengaruhi terbentuknya perilaku patuh maupun tidak patuh dalam perpajakan (Kirchler, 2007; Lewis, 1982, 2008; Torgler, 2007). Penelitian terdahulu yang mengkaji perilaku kepatuhan pajak dari perspektif psikologi 
dan ilmu sosial cenderung mengasosiasikan pajak dengan konsep persepsi (Burton, Karlinsky, \& Blanthorne, 2005; Rosid, Evans, \& Tran-Nam, 2017; Sakurai \& Braithwaite, 2003), representasi sosial (Kirchler, 2007; Kirchler, Maciejovsky, \& Schneider, 2001; Kirchler, Niemirowski, \& Wearing, 2006; Schmolders, 1959), sikap (Bahamonde-Birke, Kunert, Link, \& Ortúzar, 2015; Dean, P., Keenan, \& Kenney, 1980; Helhel \& Ahmed, 2014; Kirchler, 1999; Niemirowski, Baldwin, \& Wearing, 2003; Song \& Yarbrough, 1978), moral pajak (Fennell \& Fennell, 2003; Scholz \& Pinney, 1995; Torgler, 2007; Torgler \& Schneider, 2004), dan norma sosial (Hofmann, Hoelzl, \& Kirchler, 2008; Wenzel, 2005).

Beberapa riset terkait representasi sosial tentang pajak telah ada, namun riset-riset tersebut berbasis data dari negara barat seperti Jerman, Austria, Inggris, Polandia, dan Australia. Sedangkan penelitian serupa dalam konteks budaya Indonesia masih sangat jarang ditemukan. Disamping itu, ditemukan bahwa tema-tema negatif lebih direpresentasikan ketika orang berpikir tentang pajak. Pada penelitian Schmolders (1960), klasifikasi tema meliputi tiga hal yaitu teknis (aturan pajak, jenis pajak), aspek negatif (perasaan tidak suka, terlalu tinggi, ekspresi marah, dan sebagainya), dan kewajiban. Sedangkan pada penelitian Kirchler (1998), klasifikasi tema berdasarkan konten-konten respon seperti kritik terhadap pemerintah, kepentingan umum, instrumen politisi, dan sebagainya. Akan tetapi, mungkin saja ada perbedaan antara populasi umum dengan populasi yang lebih spesifik. Aparatur Sipil Negara (ASN) memiliki kemampuan literasi digital lebih tinggi dan hidup di area perkotaan. Kami berasumsi bahwa representasi positif akan lebih dominan pada populasi ASN khususnya di Indonesia. Oleh karenanya, penelitian ini bertujuan untuk mengeksplorasi representasi sosial pajak pada kelompok pekerja ASN. Pendekatan representasi sosial menjadi penting karena representasi sosial menjadi landasan terbentuknya penilaian, pemaknaan, persepsi keadilan, keyakinan, kesediaan serta kemampuan untuk mematuhi aturan perpajakan (Kirchler, 2007; Moscovici, Jovchelovitch, \& Wagoner, 2001).

Representasi sosial merupakan kumpulan berbagai pengetahuan yang dihasilkan dari dan oleh fenomena kehidupan sehari-hari. Terbentuknya representasi sosial melalui proses konstruksi sosial yang saling dibagikan dengan individu lain, bukan sekedar proses kognitif individual semata. Representasi sosial digunakan untuk memahami bagaimana proses memproduksi pengetahuan tentang diri sendiri, pihak lain ataupun objek sosial lainnya yang relevan baik pada individu maupun kelompok sosial (Jovchelovitch, 2007). Lebih lanjut, pembentukan representasi sosial merupakan relasi publik yang prosesnya bergantung pada konteks contohnya situasi sosial, situasi politik, kondisi perekonomian, latar belakang sejarah yang membentuk konteks spesifik (Moscovici dkk, 2001; Wagner dkk., 1999). Dari perspektif sosiologi, representasi sosial adalah rangkaian fenomena sosial seperti sikap, nilai, norma, stereotip dan atribusi, mitos-mitos dan ideologi tentang suatu objek (Durkheim, 2010). Oleh karenanya dapat kita lihat berbagai riset menggunakan representasi sosial untuk memahami perilaku baik dalam konteks sosiobudaya, kesehatan, ekonomi, dan lainnya (Dias Neto, Figueiras, Campos, \& Tavares, 2017; Hakim, Liu, Isler, \& Woodward, 2015; Tyszka, 1994; Williamson \& Wearing, 1996).

Lebih spesifik, studi representasi sosial dalam konteks perpajakan juga telah dilakukan di beberapa negara. Salah satu studi dilakukan di Jerman, dimana hasil penelitian menunjukkan bahwa ASN memiliki asosiasi yang paling positif dibandingkan responden dari kelompok pekerja white-collar workers, bluecollar workers, entrepreneur, mahasiswa, dan kelompok pensiunan serta petani (Schmolders, 1960). Penelitian selanjutnya di Austria menunjukkan hasil yang senada dengan Schmolder. Sebagai tambahan dinyatakan bahwa pajak lebih dominan diasosiasikan dengan kurangnya nilai manfaat dalam redistribusi kekayaan dan keadilan sosial. Selain itu pajak juga memiliki konotasi negatif karena orang-orang yang tidak kooperatif berusaha menghindari dan memanipulasi laporan pajak untuk meminimalisir kontribusi pajaknya (Kirchler, 1998; Kirchler dkk., 2001). Studi lain di Amerika Latin dan Karibia (Daude \& Melguizo, 2010), Tanzania (Aiko, 2013), serta studi perpajakan dan representasi berbagai negara (Ross, 2004).

Di Indonesia, studi pajak dalam kerangka representasi sosial masih sangat jarang dilakukan. Sejauh pengetahuan peneliti, belum ada artikel publikasi pada topik representasi sosial dalam konteks perpajakan. Beberapa penelitian yang ada lebih berfokus pada penggunaan istilah persepsi yang dikaitkan dengan perpajakan, diantaranya persepsi korupsi dengan kepatuhan pajak (Aryati, 2012; Rosid dkk., 2017). Namun demikian dari hasil penelitian kami sebelumnya menunjukkan bahwa ada empat tema utama representasi sosial tentang pajak di Indonesia yaitu tema positif, negatif, kewajiban dan netral-teknikal. Selain itu, beberapa kelompok demografis spesifik menunjukkan kecenderungan dominansi representasi pajak yang berbeda-beda. Sebagai contoh, kelompok pekerja bebas dan entrepreneur menunjukkan representasi negatif paling tinggi dibandingkan kelompok pekerjaan lain. Selain itu, kelompok pekerjaan seperti pekerja sosial dan mahasiswa memiliki representasi yang lebih dominan pada tema netral. Sebaliknya, kelompok pekerjaan ASN memiliki representasi dengan frekuensi tertinggi pada tema positif. Namun demikian, hasil studi representasi pajak yang kami lakukan pada masyarakat sub-urban dan pedesaan menunjukkan hasil yang berbeda dimana representasi negatif lebih dominan muncul pada golongan pekerja ASN (Susilawati \& Hidayat, 2019a, 2019b). Dengan demikian, masih terdapat inkonsistensi hasil temuan dari demografi ASN itu sendiri. 
Kelompok pekerjaan yang berbeda memiliki representasi sosial tentang pajak yang berbeda pula. Terlebih pada ASN yang memiliki relasi individupemerintah yang berbeda dibandingkan kelompok pekerjaan lain (non-ASN). Untuk lebih memahami, perlu diketahui nilai-nilai dan budaya kerja di Instansi Pemerintah. Nilai-nilai ideal dalam masyarakat Indonesia salah satunya diturunkan dari nilai-nilai Pancasila dalam setiap silanya mulai dari berketuhanan, berperi kemanusiaan, mengedepankan persatuan, mengutamakan musyawarah, dan menjaga keadilan sosial. Nilai-nilai budaya kerja ASN diantaranya komitmen terhadap visi-misi dan tujuan organisasi; wewenang dan tanggung jawab; keikhlasan dan kejujuran; kepemimpinan dan keteladanan; kebersamaan dan dinamika kelompok kerja; dedikasi dan loyalitas; dan lainnya. Dimana nilai-nilai tersebut secara disadari maupun tidak disadari diimplementasikan dalam kehidupan seharihari sehingga mewarnai dinamika psikologis terbentuknya perilaku kerja maupun perilaku lainnya termasuk dalam konteks perpajakan (Supriyadi \& Guno, 2006; Tjakrawerdaja dkk., 2018).

Namun di lain sisi, sebagai homo economicus, setiap individu juga memiliki dorongan untuk mengoptimalkan keuntungan pribadi dan meminimalisir pengeluaran (Allingham, Michael \& Sandmo, 1972). Dalam konteks membayar pajak, individu memiliki keinginan untuk menekan sekecil mungkin kewajiban membayar pajak, tak terkecuali dari berbagai macam jenis pekerjaan yang dimiliki. Namun, faktor eksternal seperti sistem pelaporan berpotensi memengaruhi dorongan memaksimalkan keuntungan pribadi. Pada ASN berlaku with holding assessment system dimana penghitungan pajak dikerjakan oleh pihak ketiga (bendahara instansi). Dalam konteks ini, kecenderungan untuk melakukan penghindaran pajak sangat kecil terjadi (Sumantry, 2011). Meski demikian, pada pembayaran jenis pajak lainnya seperti pajak kendaraan bermotor maupun jenis lainnya dimana ada faktor peluang untuk menghindari pajak, maka kecenderungan melakukan tindakan penghindaran pajak sangat mungkin terjadi. Contohnya, dalam pelaporan kepemilikan kendaraan bermotor untuk menghindari pajak progresif, dilakukan upaya mengatasnamakan kepemilikan pada orang lain (keluarga, teman, pemilik sebelumnya). Selain itu kesadaran untuk melaporkan penghasilan dari sumber lain (pendapatan tambahan) bergantung pada bagaimana nilai-nilai moral individu beradu dengan dorongan ekonomis meminimalisasi pengeluaran. Pada beberapa sisi ini, otoritas pajak belum memiliki sistem pengawasan yang terintegrasi untuk mendapatkan data objektif terkait penghasilan tambahan di luar pekerjaan.

Berbagai penjelasan di atas menekankan pentingnya memahami representasi sosial sebagai upaya memahami sikap dan perilaku yang lebih mendalam. Terlebih pada bidang kajian kebijakan publik, dimana sudut pandang psikologi untuk membantu memahami perilaku manusia dalam konteks sosial masyarakat kurang mendapat perhatian. Hal ini terlihat dari masih minimnya berbagai literatur psikologi fiskal dalam memberikan kerangka pemikiran untuk memahami perilaku masyarakat dalam konteks relasi individu dengan pemerintah (Kirchler, 1998; Kirchler \& Maciejovsky, 2001; Susilawati \& Hidayat, 2019b). Oleh karenanya, penelitian dilakukan untuk mengeksplorasi representasi sosial tentang pajak pada ASN yang bekerja di Pemerintah Daerah.

\section{Metode Penelitian}

\section{Partisipan}

Sebanyak 200 ASN Pemerintah Kota X di Provinsi Jawa Timur dengan tingkat jabatan eselon IV telah bersedia menjadi partisipan dalam penelitian ini. Proses pengambilan data dilakukan dengan memanfaatkan adanya event kerjasama dengan Pemerintah Kota X. Total 246 peserta yang hadir dalam kegiatan tersebut, namun tidak semua bersedia berpartisipasi dalam penelitian. Pengambilan data dilakukan pada 1-3 Agustus 2018. Berikut data deskriptif berdasarkan demografis dari 200 responden. Adapun data demografis pertama yaitu berdasarkan jenis kelamin, dimana terdapat responden laki-laki sebanyak 50,50\% (101 orang) dan perempuan sebanyak 49,50\% (99 orang). Kedua, berdasarkan usia, jumlah responden terbanyak berasal dari kelompok usia 51 - 60 tahun yaitu sebesar 58,50\% (117 orang), kemudian kelompok usia 41-50 tahun sebanyak 31\% (62 orang). Lalu kelompok usia 31-40 tahun sebanyak 7\% (14 orang). Sisanya kelompok usia 51-60 tahun, 21-30 tahun, serta responden yang tidak teridentifikasi data usianya dengan persentase masing-masing kurang dari $5 \%$.

Data demografis ketiga yaitu tingkat pendidikan. Persentase jumlah responden terbanyak memiliki latar belakang pendidikan terakhir S1/sederajat yaitu sebesar 56\% (112 orang), diikuti SMA/Sederajat sebesar 21\% (42 orang), dan S2/Profesi/Spesialis sebesar 19,5\% (39 orang). Sisanya yaitu pendidikan D1-DIII, S3, dan kelompok responden yang tidak teridentifikasi datanya memiliki persentase lebih kecil yaitu kurang dari 5\%. Selanjutnya, data demografis keempat yaitu tingkat penghasilan. Kelompok responden terbanyak berasal dari responden dengan tingkat penghasilan Rp.1.100.000 - 5.000.000 yaitu sebesar 60\% (120 orang), diikuti kelompok tingkat penghasilan Rp. 5.100 .000 - 10.000.000 sebesar 36\% (72 orang). Sedangkan kelompok dengan tingkat penghasilan dalam rentang Rp. 10.100.000 - 50.000.000 dan penghasilan lebih dari Rp. 50 juta memiliki persentase kecil kurang dari 5\%.

\section{Pengukuran}

Penelitian ini menggunakan pendekatan kualitatif. Pengambilan data menggunakan kuesioner dengan pertanyaan terbuka 'apa yang Anda pikirkan 
dan rasakan ketika mendengar kata pajak?'. Kerangka pembuatan kuesioner mengacu pada Schmolders (dalam Kirchler, 2007). Dengan asumsi asosiasi bebas, individu cenderung akan merespon pertanyaan terbuka berdasarkan kerangka asosiatif kognisi yang diwarnai oleh berbagai pandangan, pengalaman subyektif dan keyakinan baik rasional maupun irasional yang dimiliki.

\section{Analisis data}

Proses analisis data kualitatif dengan descriptive content analysis. Dimana content analysis merupakan salah satu metode analisis yang sesuai untuk menggambarkan karakteristik substansial dari isi pesan, karakteristik bentuk pesan, dan membuat kesimpulan dari isi pesan (Neuendorf, 2002). Mengacu pada Neuendorf (2002), proses pengambilan kesimpulan dilakukan secara induktif, melalui tahapan teori dan latar belakang penentuannya. Diikuti dengan langkah konseptualisasi variabel dan definisi konseptual. Proses operasionalisasi menggunakan by-utterance coding scheme atau analisis ucapan atau ungkapan yang dituangkan melalui survei. Skema koding melalui proses pembuatan kamus kata yang merupakan hasil kesepakatan para rater. Selanjutnya, pilot reliability dilakukan melalui inter-rater meeting untuk penyamaan pemahaman dan pembatasan makna dan bahasa yang digunakan. Dalam melakukan koding, tiap kelompok data dikoding oleh tiga orang rater hingga menemukan kesepakatan final pada subkategori, kategori dan tema akhir yang digunakan (Susilawati \& Hidayat, 2019b).

Dari 200 responden diperoleh sebanyak 462 kode kata. Kesepakatan kode kata antar rater mencapai angka kesepakatan terbilang tinggi yaitu 96,97\%. Angka ini banyak terbantu melalui proses analisis data pada dua kelompok data sebelumnya, dimana kamus kata dan kode-kode kata telah terbentuk lebih adekuat dan konsisten, sehingga mempermudah rater dalam melakukan koding data dengan lebih terstandar. Dari sebanyak 462 kode kata dilakukan proses penyaringan kode kata dan dengan menyatukan kode kata yang sama atau memiliki kesamaan total kode kata dapat direduksi menjadi 94 kode. Selanjutnya, dilakukan proses kategorisasi data lebih lanjut atau disebut tahap reduksi tingkat 2 diperoleh 34 subkategori kata. Selanjutnya tahap reduksi tingkat 3 menghasilkan 18 kategori. Terakhir yaitu tahap reduksi tingkat 4 yaitu pembuatan tema kata, terdapat empat tema utama yaitu positif, netral, kewajiban, dan negatif. Ditambah dengan satu tema untuk kode-kode kata yang tidak bisa masuk dalam 4 tema utama lainnya, disebut tidak terkategorisasikan.

Tabel 1. Representasi sosial pajak pada ASN

\begin{tabular}{lcc}
\hline \multicolumn{1}{c}{ Tema } & Frekuensi & Prosentase (\%) \\
\hline Negatif & $\mathbf{7 0}$ & $\mathbf{1 5 , 1 5 \%}$ \\
Beban & 29 & $\mathbf{6 , 2 8 \%}$ \\
Kompleksitas & 14 & $3,03 \%$ \\
Penyelewengan & 4 & $0,87 \%$ \\
sikap negatif & 22 & $4,76 \%$ \\
tindakan semena-mena & 1 & $0,22 \%$ \\
Netral & $\mathbf{8 8}$ & $\mathbf{1 9 , 0 5 \%}$ \\
Bayar & 5 & $1,08 \%$ \\
Ekonomi & 3 & $0,65 \%$ \\
istilah teknis pajak & 2 & $0,43 \%$ \\
jenis pajak & 6 & $1,30 \%$ \\
Mekanisme & 60 & $12,99 \%$ \\
Regulasi negara & 3 & $0,65 \%$ \\
sikap netral & 8 & $1,73 \%$ \\
Positif & $\mathbf{3 0 3}$ & $\mathbf{6 5 , 5 8 \%}$ \\
kepentingan bersama & 108 & $23,38 \%$ \\
Kontribusi & 12 & $2,60 \%$ \\
sikap positif & 60 & $12,99 \%$ \\
Rasa kewajiban & 123 & $26,62 \%$ \\
tidak terkategorisasikan & $\mathbf{1}$ & $\mathbf{0 , 2 2 \%}$ \\
\hline Total & 462 & $\mathbf{1 0 0 , 0 0 \%}$ \\
\hline
\end{tabular}




\section{Hasil Penelitian}

Hasil penelitian menunjukkan adanya empat tema dalam representasi sosial tentang pajak pada masyarakat dari kelompok pekerja ASN yaitu positif, netral-teknikal, dan negatif. Secara berurutan dari persentase asosiasi pajak tertinggi adalah positif yaitu sebesar 65,58\% (303 dari 462 kode kata). Selanjutnya diikuti dengan netral-teknikal yaitu sebesar 19,05\% (88 dari 462 kode kata) dan terendah adalah negatif sebesar 15,15\% (70 dari 462 kode kata). Tabel 1 memaparkan tema beserta subtema yang muncul dari hasil penelitian ini.

Berdasarkan hasil analisis data, representasi sosial tentang pajak pada kelompok ASN dapat dikategorikan berdasarkan spektrum evaluasi yang bergerak dari representasi positif, netral dan negatif. Tiga tema utama dari representasi sosial tentang pajak pada kelompok pekerja ASN: Pertama, positif. Asosiasi positif diartikan sebagai penilaian subjektif individu yang berorientasi pada nilai-nilai positif dan dukungan terhadap pajak. Tema positif mewakili berbagai asosiasi kata dalam empat subkategori yaitu 1) Kepentingan bersama meliputi kode kata kepentingan umum, pembangunan, kesejahteraan rakyat, kepentingan masyarakat, kemajuan negara, kepentingan negara, pendapatan negara, dan pembiayaan negara; 2) Kontribusi, meliputi kode kata kontribusi dan dana masyarakat; 3) Sikap positif meliputi anggapan bahwa pajak bernilai positif (penting, baik, bermanfaat), menunjukkan perilaku kepatuhan (patuh bayar, patuh pajak), serta sikap positif lainnya (ajakan patuh, ikhlas, mendukung, menjadi teladan, kepuasan, sadar pajak, serta rasa senang). 4) Rasa kewajiban mewakili kata-kata kewajiban sebagai warga negara, wajib bayar, wajib taat, dan rasa tanggung jawab.

Kedua, netral-teknikal. Asosiasi netral diartikan sebagai penilaian subjektif individu yang berorientasi pada informasi-informasi yang mendeskripsikan berbagai pengetahuan teknis yang terkait dengan kata 'pajak'. Tema netral-teknikal mewakili subkategori mekanisme (resiprositas, berbatas waktu, sanksi, bersifat memaksa, tidak menerima manfaat langsung, mekanisme pembayaran, prinsip integritas, prinsip keadilan, prinsip perbaikan berkelanjutan, prinsip edukasi, prinsip simplisitas, prinsip transparansi); jenis pajak (Pajak Penghasilan, Pajak Bumi dan Bangunan, Pajak Kendaraan); sikap netral (hal biasa, tidak masalah); bayar; ekonomi (finansial); regulasi negara; objek pajak.

Ketiga, negatif. Asosiasi negatif diartikan sebagai evaluasi subjektif individu yang berorientasi pada nilai-nilai negatif terhadap pajak. Tema negatif mewakili subkategori beban (beban, beban finansial, memberatkan, pengeluaran, potongan, pungutan, semua kena pajak, tinggi); kompleks (rumit, ribet, pusing); sikap negatif meliputi berbagai kritikan terhadap pemerintah (contohnya distribusi tagihan lambat, ketidakadilan, pemberlakuan aturan dan prosedur yang masih lemah, sanksi hukum kurang tegas, dan sistem belum terintegrasi), ekspresi sikap negatif (seperti kata menakutkan, pesimis, tidak percaya, tidak peduli), tendensi ketidakpatuhan (seperti dihindari, enggan berbuat jujur, enggan mengurus sendiri, kurang keinginan membayar, menunda pembayaran); penyelewengan (korupsi, penyelewengan); dan tindakan semena-mena (upeti).

\section{Analisis demografi partisipan}

Hasil analisis berdasarkan klasifikasi demografis juga disajikan. Pertama gambaran asosiasi pajak berdasarkan jenis kelamin. Sebagaimana yang telah dideskripsikan pada bagian metode. Perbandingan responden laki-laki dan perempuan yaitu 101: 99 responden, menghasilkan sebanyak 228 respon dari kelompok laki-laki, dan 234 respon dari kelompok perempuan. Berdasarkan skema koding per kata, diperoleh hasil bahwa pada kedua kelompok baik laki-laki maupun perempuan memiliki asosiasi pajak secara berurutan dari yang terkuat hingga terlemah yaitu positif, netral-teknikal, dan terakhir negatif. Data numerik lebih detail dapat dilihat pada tabel 2 ini.

Hasil analisis deskriptif berdasarkan karakteristik demografis kedua yaitu usia. Responden dalam penelitian ini dominan dari kelompok usia 51 - 60 tahun, kemudian 41 - 50 tahun, dan 31 - 40 tahun. Pada hasil analisis deskriptif yang lebih detail terlihat bahwa pada seluruh kelompok usia didominasi dengan asosiasi positif sebagai yang terkuat dalam merepresentasikan kata pajak. Lebih jauh, semakin tinggi usia, semakin konsisten individu memandang pajak berkaitan erat dengan hal-hal positif dan netral-teknikal.

Hasil analisis deskriptif berdasarkan karakteristik demografis ketiga yaitu tingkat pendidikan. Mayoritas responden dalam penelitian ini berlatar belakang pendidikan S1/Sederajat, SMA/Sederajat, dan S2/Profesi/Spesialis dengan persentase $56 \%, 21 \%, 19,50 \%$. Hasil yang lebih spesifik menunjukkan bahwa pada semua kelompok latar belakang pendidikan yang berbeda memiliki asosiasi positif sebagai asosiasi dengan frekuensi tertinggi. Dari semua kelompok, hanya responden dengan latar belakang pendidikan S2 yang menunjukkan asosiasi tertinggi kedua didominasi asosiasi negatif. Sedangkan kelompok lainnya menunjukkan dominasi tertinggi kedua pada asosiasi netral-teknikal.

Berikutnya, kelompok demografis keempat yaitu tingkat penghasilan. Berdasarkan hasil analisis deskriptif diketahui bahwa responden dalam penelitian ini didominasi oleh individu dengan tingkat penghasilan dalam rentang Rp.1.100.000 - 5.000.000 dan Rp. 5.100.000 - 10.000.000 dengan persentase $59,50 \%$ dan $36 \%$. Hasil yang lebih detail juga menunjukkan bahwa pada seluruh kelompok responden dengan tingkat penghasilan yang berbeda menunjukkan asosiasi tertinggi pada tema positif, diikuti dengan tema kewajiban dan netral. 
Tabel 2. Representasi sosial tentang pajak berdasarkan jenis kelamin

\begin{tabular}{|c|c|c|c|c|}
\hline \multirow[b]{2}{*}{ Tema } & \multicolumn{2}{|c|}{ Laki-laki } & \multicolumn{2}{|c|}{ Perempuan } \\
\hline & $\begin{array}{l}\text { Jumlah } \\
\text { respon }\end{array}$ & Persentase & $\begin{array}{l}\text { Jumlah } \\
\text { respon }\end{array}$ & Persentase \\
\hline Negatif & 31 & $6.71 \%$ & 39 & $8,44 \%$ \\
\hline Netral & 43 & $9,31 \%$ & 45 & $9,74 \%$ \\
\hline Positif & 154 & $33,33 \%$ & 149 & $32,25 \%$ \\
\hline Tidak terkategorisasikan & 0 & 0 & 1 & $0,22 \%$ \\
\hline Total & 228 & $49,35 \%$ & 234 & $50,65 \%$ \\
\hline
\end{tabular}

Tabel 3. Asosiasi pajak berdasarkan usia

\begin{tabular}{|c|c|c|c|c|c|c|c|c|c|c|c|}
\hline \multirow[b]{2}{*}{ Usia } & \multicolumn{2}{|c|}{$21-30$} & \multicolumn{2}{|c|}{$31-40$} & \multicolumn{2}{|c|}{$41-50$} & \multicolumn{2}{|c|}{$51-60$} & \multicolumn{2}{|c|}{ Tidak terisi } & \multirow{2}{*}{$\begin{array}{l}\text { Total } \\
\text { Total }\end{array}$} \\
\hline & $\begin{array}{l}\text { Jumlah } \\
\text { Respon }\end{array}$ & $\%$ & $\begin{array}{l}\text { Jumlah } \\
\text { Respon }\end{array}$ & $\%$ & $\begin{array}{l}\text { Jumlah } \\
\text { Respon }\end{array}$ & $\%$ & $\begin{array}{l}\text { Jumlah } \\
\text { Respon }\end{array}$ & $\%$ & $\begin{array}{l}\text { Jumlah } \\
\text { Respon }\end{array}$ & $\%$ & \\
\hline Negatif & 0 & 0 & 9 & $1,95 \%$ & 27 & $5,84 \%$ & 33 & $7,14 \%$ & 1 & $0,22 \%$ & 70 \\
\hline Netral & 0 & 0 & 11 & $2,38 \%$ & 27 & $5,84 \%$ & 49 & $10,61 \%$ & 1 & $0,22 \%$ & 88 \\
\hline Positif & 3 & $0,65 \%$ & 17 & $3,68 \%$ & 102 & $22,08 \%$ & 102 & $37,23 \%$ & 5 & $1,95 \%$ & 180 \\
\hline $\begin{array}{l}\text { Tidak } \\
\text { Terkate- } \\
\text { gorisasi- } \\
\text { kan }\end{array}$ & 0 & 0 & 0 & - & 0 & 0 & 1 & $0,22 \%$ & 0 & 0 & 1 \\
\hline Total & 3 & $0,65 \%$ & 37 & $8,01 \%$ & 156 & $33,77 \%$ & 255 & $55,19 \%$ & 11 & $2,38 \%$ & 462 \\
\hline
\end{tabular}

Tabel 4. Asosiasi pajak berdasarkan Tingkat Pendidikan

\begin{tabular}{|c|c|c|c|c|c|c|c|c|c|}
\hline \multirow[b]{2}{*}{ Tingkat Pendidikan } & \multicolumn{2}{|c|}{ Negatif } & \multicolumn{2}{|c|}{ Netral } & \multicolumn{2}{|c|}{ Positif } & \multicolumn{2}{|c|}{$\begin{array}{c}\text { Tidak } \\
\text { terkategorisasi }\end{array}$} & \multirow{2}{*}{$\begin{array}{l}\text { Total } \\
\text { Total }\end{array}$} \\
\hline & $\begin{array}{l}\text { Jumlah } \\
\text { Respon }\end{array}$ & $\%$ & $\begin{array}{l}\text { Jumlah } \\
\text { Respon }\end{array}$ & $\%$ & $\begin{array}{l}\text { Jumlah } \\
\text { Respon }\end{array}$ & $\%$ & $\begin{array}{l}\text { Jumlah } \\
\text { Respon }\end{array}$ & $\%$ & \\
\hline SMA/Sederajat & 10 & $2,16 \%$ & 15 & $3,25 \%$ & 58 & $12,55 \%$ & 1 & $0,22 \%$ & 84 \\
\hline D1 - DIII & 0 & - & 4 & $0,87 \%$ & 9 & $1,95 \%$ & 0 & - & 13 \\
\hline S1/Sederajat & 36 & $7,79 \%$ & 48 & $10,39 \%$ & 171 & $37,01 \%$ & 0 & - & 255 \\
\hline S2/Profesi/Spesialis & 24 & $5,19 \%$ & 20 & $4,33 \%$ & 62 & $13,42 \%$ & 0 & - & 106 \\
\hline S3 & 0 & - & 0 & - & 2 & $0,43 \%$ & 0 & - & 2 \\
\hline Tidak terisi & 0 & - & 1 & $0,22 \%$ & 1 & $0,22 \%$ & 0 & - & 2 \\
\hline Total & 70 & $15,15 \%$ & 88 & $19,05 \%$ & 303 & $38,96 \%$ & 1 & $0,22 \%$ & 462 \\
\hline
\end{tabular}

Tabel 5. Asosiasi pajak berdasarkan Tingkat Penghasilan

\begin{tabular}{|c|c|c|c|c|c|c|c|c|c|}
\hline \multirow{2}{*}{$\begin{array}{c}\text { Tingkat Penghasilan } \\
\text { (Rupiah) }\end{array}$} & \multicolumn{2}{|c|}{ negatif } & \multicolumn{2}{|c|}{ netral } & \multicolumn{2}{|c|}{ Positif } & \multicolumn{2}{|c|}{ tidak terkategori } & \multirow[t]{2}{*}{ Total } \\
\hline & $\begin{array}{l}\text { Jumlah } \\
\text { Respon }\end{array}$ & $\%$ & $\begin{array}{l}\text { Jumlah } \\
\text { Respon }\end{array}$ & $\%$ & $\begin{array}{l}\text { Jumlah } \\
\text { Respon }\end{array}$ & $\%$ & $\begin{array}{l}\text { Jumlah } \\
\text { Respon }\end{array}$ & $\%$ & \\
\hline $1.100 .000-5.000 .000$ & 39 & $8,44 \%$ & 48 & $10,39 \%$ & 174 & $37,66 \%$ & 0 & - & 261 \\
\hline $5.100 .000-10.000 .000$ & 29 & $6,28 \%$ & 36 & $7,79 \%$ & 117 & $25,32 \%$ & 1 & $0,22 \%$ & 183 \\
\hline $10.100 .000-50.000 .000$ & 0 & - & 2 & $0,43 \%$ & 4 & $0,87 \%$ & 0 & - & 6 \\
\hline$>50.000 .000$ & 1 & $0,22 \%$ & 2 & $0,43 \%$ & 5 & $1,08 \%$ & 0 & - & 8 \\
\hline Tidak terisi & 1 & $0,22 \%$ & 0 & - & 3 & $0,65 \%$ & 0 & - & 4 \\
\hline Total & 70 & $15,15 \%$ & 88 & $19,05 \%$ & 303 & $65,58 \%$ & 1 & $0,22 \%$ & 462 \\
\hline
\end{tabular}




\section{Diskusi}

Berdasarkan uraian hasil analisis deskriptif diatas dapat disimpulkan bahwa secara umum responden dari kelompok pekerjaan Aparatur Sipil Negara (ASN) memiliki representasi positif terhadap pajak. Apabila dilihat lebih jauh, simpulan tersebut diperkuat dengan hasil yang konsisten. Meskipun dilihat dari berbagai karakteristik demografis yang berbeda baik jenis kelamin, usia, tingkat pendidikan, tingkat penghasilan, menunjukkan hasil yang mendukung. Demikian juga dilihat dari analisis per responden maupun per kata juga menunjukkan hasil yang selaras, dimana pajak direpresentasikan sebagai hal yang positif, kewajiban, netral-teknikal, dan terakhir adalah negatif.

Untuk mengulas secara lebih mendalam penulis menyajikan kembali data hasil studi sebelumnya. Hasil dari survei daring pada berbagai kelompok jenis pekerjaan menunjukkan bahwa pada kelompok pekerjaan ASN dengan total responden 112 orang memiliki asosiasi terkuat dengan positif, kewajiban, netral-teknikal, dan negatif secara berurutan (Susilawati \& Hidayat, 2019b). Berbeda dengan hasil studi kedua yang peneliti lakukan secara konvensional dengan pertemuan person to person. Dari total 14 responden menunjukkan asosiasi secara berurutan dari yang tertinggi yaitu negatif, positif, netral-teknikal, dan kewajiban (Susilawati \& Hidayat, 2019a). Hasil yang selaras dinyatakan dari penelitian sebelumnya, bahwa ASN merupakan kelompok pekerjaan yang memiliki asosiasi terendah pada tema negatif (Kirchler, 1998; Schmolders, 1960).

Secara umum, tampak adanya keselarasan temuan pada studi khusus kelompok ASN dengan studi survei daring. ASN dominan memiliki representasi positif terhadap pajak. Asosiasi pajak sebagai sarana untuk pembangunan, sebagai sumber pendapatan negara, untuk kepentingan umum, kesejahteraan rakyat, sebagai bentuk kontribusi terhadap negara, pentingnya hasil memiliki kesadaran pajak, melakukan tindakan-tindakan kepatuhan baik dalam membayar maupun melapor, hingga memaknai pajak sebagai hal yang penting dan bernilai untuk bersama. Selain itu juga representasi pajak sebagai sebuah kewajiban yang harus dilakukan. Kedua representasi ini melandasi perilaku mereka dalam hal perpajakan.

Hasil representasi juga menunjukkan kuatnya konteks sosial budaya di masyarakat Indonesia yang kolektivis. Rasa kekeluargaan, mengutamakan kepentingan bersama di atas kepentingan pribadi, rasa keadilan sosial menjadi nilai-nilai moral dasar yang mengendalikan perilaku individu dalam hidup bermasyarakat. Selain itu, misalnya pada masyarakat Jawa yang memegang teguh nilai 'sepi ing pamrih' yaitu menahan diri untuk tidak egois dan berusaha mendahulukan kewajiban-kewajiban atas kedudukannya dalam tatanan masyarakat (pandangan dimana ASN sebagai abdi negara atau pelayan masyarakat). Hal tersebut menjadi dasar untuk menjelaskan kesadaran pribadi individu khususnya di kalangan
ASN dalam mewujudkan perilaku kepatuhan dalam perpajakan (Tjakrawerdaja et al., 2018).

Apabila dilihat dari karakteristik ASN, salah satu etika sebagai pelayan publik adalah nilai kesetiaan pada tugas dan pada pemerintah, selanjutnya disebut sense of duty. ASN memiliki nilai motivasi dasar, salah satunya patriotisme dan dorongan untuk berbuat kebajikan (Perry \& Wise, 1990). Semangat patriotisme dan dorongan untuk berbuat kebajikan merupakan perpaduan rasa cinta terhadap pemerintah dengan rasa cinta terhadap sesama yang menghadirkan rasa kesediaan berkorban pada sesama. Rasa patriotisme tersebut merupakan kondisi emosional yang menjelma menjadi nilai-nilai moral yang harus dimiliki dan diinternalisasi oleh ASN. Membayar pajak diartikan sebagai sebuah rasa kewajiban moral untuk berkontribusi terhadap negara sekaligus berbagi pada sesama untuk distribusi kesejahteraan rakyat yang lebih merata.

Lebih lanjut, pernyataan Tjakrawerdaja dkk (2018) menegaskan bahwa rasa keadilan sosial yang dominan pada manusia Indonesia dilandasi oleh keselarasan antara kewajiban dan hak. Demikian pula Kirchler (1998) menyatakan bahwa persepsi keseimbangan dalam relasi pertukaran individupemerintah merupakan determinan perilaku perpajakan. Lebih jauh, persepsi keadilan diartikan sebagai sebuah keseimbangan antara apa yang diberikan dengan apa yang diperoleh dari negara, tergantung pada relasi antara keuntungan aktual individual dengan fasilitas umum yang diharapkan, sebagaimana juga dengan tingkat pendapatan responden. Hal ini dapat menjelaskan asosiasi positif ASN terhadap pajak, dimana ASN mengasosiasikan gaji yang mereka peroleh merupakan hasil dari pajak sehingga semakin tinggi pendapatan negara melalui sektor pajak, semakin tinggi pula harapan kesejahteraan finansial yang bisa mereka peroleh. Selain itu, berbagai sumber dana untuk menjalankan berbagai aktivitas kerja di Pemerintah Kota juga berasal dari pajak.

Dilain sisi kelompok ASN memiliki representasi negatif yang paling rendah dibandingkan dengan kelompok pekerjaan lain dalam memandang pajak. Hal ini bisa dijelaskan dari persepsi pertukaran hak-kewajiban yang memandang bahwa individu menerima lebih banyak hak dari perolehan pajak daripada kewajibannya. Selain itu, Schmolders (1960) menambahkan bahwa pegawai yang hanya menerima gaji bulanan dan menyadari gaji bruto dan pemotongan pajak hanya "diatas kertas" mungkin kurang menyadari pembayaran pajak mereka dan mungkin menganggap pajak bukan sebagai kehilangan finansial yang nyata (Kirchler, 1998). Sistem penggajian dan sistem pemotongan pajak pada ASN yang berjalan saat ini membuat responden kurang merasakan potongan pajak (khusus pajak penghasilan) pada gaji karena pendapatannya sudah otomatis tertransfer sebagai gaji bersih.

Dari seluruh uraian sebelumnya, dapat dikatakan bahwa representasi sosial tentang pajak 
pada ASN didominasi tema positif yang didalamnya terkandung unsur penilaian terhadap nilai manfaat, tujuan bersama, dan rasa kewajiban moral sebagai hubungan timbal balik hak dan kewajiban yang melekat dari tuntutan peran pekerjaannya sebagai ASN. Kewajiban dirasakan sebagai sesuatu yang harus dilakukan dan dipaksakan namun dengan kesadaran bahwa kewajiban tersebut memiliki nilai penting dan positif bagi keutuhan, persatuan dan kehidupan bermasyarakat serta bernegara. Representasi sosial yang bercorak positif tersebut kemudian membawa individu pada sikap positif terhadap pajak diantaranya ditunjukkan melalui ekspresi rasa senang, bangga, dukungan terhadap adanya pajak, kesediaan membayar, kesadaran pajak, hingga sikap untuk mempengaruhi orang lain berperilaku sama. Sebagaimana yang dinyatakan oleh Groenland dan Van Veldhoven (1983) dan Lewis (1982) bahwa karakteristik personal, nilai-nilai ideologi dan religi, dan orientasi moral memengaruhi perilaku perpajakan.

Sikap positif terhadap pajak yang dominan disertai dengan sistem administrasi pelaporan dan pembayaran yang dikelola oleh pihak ketiga (withholding assessment system) diasumsikan sebagai faktor pendorong individu menunjukkan perilaku kepatuhan dan meminimalisasi perilaku penyimpangan pajak. Dilain sisi, dengan penuh pengharapan bahwa pemerintah juga akan membenahi sistem sehingga hal-hal yang menyebabkan individu memiliki pandangan negatif dapat berangsur diminimalisasi, seperti tingginya celah korupsi, penindakan hukum yang belum tegas, hingga beban pajak yang dirasakan terlalu tinggi. Sikap positif berkorelasi positif dengan intensi perilaku sebagai norma yang kuat yang mengarahkan individu pada perilaku tertentu (Kirchler, 2007; Lewis, 1982). Rasa kewajiban moral memberi pengaruh tambahan terhadap terbentuknya perilaku (Bobek \& Hatfield, 2003). Maka, dapatlah dikatakan bahwa representasi kognitif dan representasi sosial terhadap pajak dan memahami faktor yang dimungkinkan mempengaruhi ter-bentuknya asosiasi positif terhadap pajak merupakan hal penting untuk memahami sikap dan perilaku individu dalam hal perpajakan (Kirchler, 1998, 2007). Tentunya tanpa mengesampingkan pendekatan makro-ekonomi yang lebih bersifat sistemis.

\section{Kesimpulan}

Tujuan dari penelitian ini adalah untuk mengidentifikasi apakah pada kelompok pekerjaan ASN menunjukkan representasi sosial yang berbeda dengan kelompok pekerjaan lainnya. Pada dua studi sebelumnya yang dilakukan peneliti, menunjukkan bahwa pada kelompok pekerjaan yang berbeda menghasilkan representasi sosial yang berbeda pula tentang pajak (Susilawati \& Hidayat, 2019b, 2019a). Hal ini juga dilandasi oleh beberapa penelitian sebelumnya yang dilakukan di negara lain yaitu Austria dan Jerman yang menunjukkan simpulan senada (Kirchler, 1998; Schmolders, 1960). Diantara berbagai jenis pekerjaan yang ada, kelompok ASN menunjukkan konsistensi representasi positif yang dominan terhadap pajak.

Representasi sosial tentang pajak yang bercorak positif pada ASN, khususnya yang berhubungan dengan nilai-nilai nasionalisme, patriotisme, kontribusi pada keadilan sosial dan kesejahteraan bersama perlu ditelaah lebih lanjut melalui studi empiris yang lebih kuat, misalnya dengan pengujian eksperimental untuk melihat apakah nilai-nilai tersebut juga berasosiasi kuat pada pandangan masyarakat umum lainnya. Kemudian hasil tersebut dapat digunakan sebagai bahan kajian untuk memberikan usulan dalam hal pola dan cara sosialisasi perpajakan yang lebih efektif. Namun demikian perlu pula diperhatikan faktor eksternal seperti sistem administrasi perpajakan yang berlaku dan peluang-peluang bagi individu untuk melakukan tindakan penghindaran ataupun penyimpangan pajak. Jadi, pendekatan makro-ekonomis tetap perlu ditekankan, dilain sisi pengembangan nilai-nilai moral positif juga perlu ditingkatkan melalui pendekatan mikro-ekonomis atau perilaku ekonomi untuk meningkatkan regulasi diri dalam menghadapi dilema sosial peran individu sebagai homo socius sekaligus homo economicus.

\section{Daftar Pustaka}

Aiko, R. (2013). Do I Have To Pay Tax? Citizens ' Awareness of Their Tax Obligations. In Afrobarometer Briefing Paper.

Allingham, Michael, G., \& Sandmo, A. (1972). Income tax evasion: A theoretical analysis. Journal of Public Economics, 1, 323-338. doi: 10.1016/0047-2727(72)90010-2

Ameyaw, B., Oppong, A., Aba Abruquah, L., \& Ashalley, E. (2016). Informal Sector Tax Compliance Issues and the Causality Nexus between Taxation and Economic Growth: Empirical Evidence from Ghana. Modern Economy, 07(12), 1478-1497. doi:10.4236/me.2016.712134. doi: 10.4236/me.2016.712134

Aryati, T. (2012). Analisis faktor-faktor yang mempengaruhi tingkat kepatuhan Wajib Pajak Badan. Media Ekonomi Dan Manajemen, 25(1), 13-29.

Bahamonde-Birke, J., F., Kunert, U., Link, H., \& Ortúzar, J. D. D. (2015). About attitudes and perceptions finding the proper way to consider latent variables in discrete choice models. German Institute for Economic Research.

Bobek, D. ., \& Hatfield, R. . (2003). An investigation of the theory of planned behavior and the role of moral obligation in tax compliance. Behavioral Research in Accounting, 15(1), 13-38. doi: 10.2308/bria.2003.15.1.13

Burton, H., Karlinsky, S., \& Blanthorne, C. (2005). Perception of a white-collar crime: Tax evasion. American Taxation Association Journal of Legal 
Tax Research, 3(1), 35-48. doi: 10.2308/jltr.2005.3.1.35.

Daude, C., \& Melguizo, A. (2010). Taxation and more representation? on fiscal policy, social mobility and democracy in Latin America. In OECD Development Centre Working Paper No. 294. doi: $10.1787 / 5 \mathrm{~km} 5 \mathrm{zrrs} 9 \mathrm{bbt}-\mathrm{en}$

Daude, C., \& Melguizo, A. (2017). Taxation and more representation? on fiscal policy, social mobility and democracy in Latin America. In OECD Development Centre Working Paper No. 294. doi: 10.1016/j.nbd.2015.08.009.

Dean, P., Keenan, T., \& Kenney, F. (1980). Taxpayer's attitude to income tax evasion: An empirical study. British Tax Review, 25, 28-44.

Dias Neto, D., Figueiras, M. J., Campos, S., \& Tavares, P. (2017). Impact of economic crisis on the social representation of mental health: Analysis of a decade of newspaper coverage. International Journal of Social Psychiatry, 63(8), 736-743. doi: 10.1177/0020764017737102.

Direktorat Jenderal Pajak. (2016). Refleksi Tingkat Kepatuhan Wajib Pajak Direktorat Jenderal Pajak. Retrieved from http://www.pajak.go.id/content/article/reflek si-tingkat-kepatuhan-wajib-pajak.

Direktorat Penyusunan APBN, \& Direktorat Jenderal Anggaran. (2019). Informasi APBN 2019. Kementerian Keuangan Republik Indonesia.

Durkheim, E. (2010). Sociology and Philosophy. New York: Routledge Revivals.

Fennell, C. C., \& Fennell, L. A. (2003). Fear and greed in tax policy: A qualitative research Agenda. Washington University Journal of Law and Policy, 13,75-138. doi: 10.2139/ssrn.474360.

Griffith, R., O'Connell, M., \& Smith, K. (2019). Tax design in the alcohol market. Journal of Public Economics, 172, 20-35. doi: 10.1016/j.jpubeco.2018.12.005.

Hakim, M. A., Liu, J. H., Isler, L., \& Woodward, M. R. (2015). Monarchism, national identity and social representations of history in Indonesia : Intersections of the local and national in the sultanates of Yogyakarta and Surakarta. Asian Journal of Social Psychology, 18 (4), 259-269. doi: 10.1111/ajsp.12109.

Helhel, Y., \& Ahmed, Y. (2014). Factors Affecting Tax Attitudes and Tax Compliance: A Survey Study in Yemen Article. European Journal of Business and Management Online, 6(22), 2222-2839. doi: 10.21275/ART20163576.

Hofmann, E., Hoelzl, E., \& Kirchler, E. (2008). Preconditions of Voluntary Tax Compliance. Zeitschrift Für Psychologie / Journal of Psychology, 216(4), 209-217. doi: 10.1027/0044-3409.216.4.209.

Huseynov, F., \& Klamm, B. K. (2012). Tax avoidance, tax management and corporate social responsibility. Journal of Corporate Finance, 18(4), 804-827. doi: 10.1016/j.jcorpfin.2012.06.005.

Jovchelovitch, S. (2007). Knowledge in Context:
Representations, community and culture. Routledge, Taylor \& Francis Group. doi: 10.4324.9781315173368.

Kirchler, E. (1998). Differential representations of taxes: Analysis of free associations and judgments of five employment groups. Journal of Socio-Economics, 27(1), 117-131. doi: 10.1016/s1053-5357(99)80080-8.

Kirchler, E. (1999). Reactance to taxation : Employers' attitudes towards taxes. Journal of SocioEconomics, 28 (2), 131-138. doi: 10.1016/s1053-5357(99)00003-7.

Kirchler, E. (2007). The economic psychology of tax behaviour. Cambridge: Cambridge University Press. doi: 10.1017/CB09780511628238.

Kirchler, E., \& Maciejovsky, B. (2001). Tax compliance within the context of gain and loss situations, expected and current asset position, and profession. Journal of Economic Psychology, 22 (2), 173-194. doi: 10.1016/s01674870(01)00028-9.

Kirchler, E., Maciejovsky, B., \& Schneider, F. (2001). Everyday representations of tax avoidance, tax evasion, and tax flight: Do legal differences matter? Journal of Economic Psychology, 24(4), 535-553. doi: 10.1016/S0167-4870(02)001642.

Kirchler, E., Niemirowski, A., \& Wearing, A. (2006). Shared subjective views, intent to cooperate and tax compliance: Similarities between Australian taxpayers and tax officers. Journal of Economic Psychology, 27(4), 502-517. doi: 10.1016/j.joep.2006.01.005.

Lewis, A. (1982). The social psychology of taxation. British Journal of Social Psychology, 21(2), 151158.doi: 10.1111/j.2044-8309.1982.tb00523.x.

Lewis, A. (2008). Psychology and economic behaviour. Cambridge: Cambridge University Press. doi: 10.1017/cbo9780511490118.

Moscovici, S., Jovchelovitch, S., \& Wagoner, B. (2001). Development as a social process: contributions of Gerard Duveen. London: Routledge, Taylor \& Francis Group. doi: 10.4324/9780203387979.

Neuendorf, K. A. (2002). The Content Analysis Guidebook. (Margaret H. Seawell, Ed.). California: Sage Publications.

Niemirowski, P., Baldwin, S., \& Wearing, A. J. (2003). Tax related behaviours, beliefs, attitudes and values and taxpayer compliance in Australia. Journal of Australian Taxation, 6(1), 131-165. Retrieved from https://scholar.google.com/scholar?cluster=13 882879297702468973\&hl=en\&as_sdt=0,5

Oktara, D. (2017). Kepatuhan Pajak di Indonesia Masih Rendah. Tempo. Retrieved from /Kepatuhan Pajak di Indonesia Masih Rendah Bisnis Tempo.co.html.

Perry, J. L., \& Wise, L. (1990). The motivational bases of public service. Public Administration Review, 50(3), 367-373. doi: 10.2307/976618.

Rosid, A., Evans, C., \& Tran-Nam, B. (2017). Perceptions of corruption and tax non- 
compliance behaviour: policy implications for developing countries. Bulletin of Indonesian Economic Studies, 54(1), 25-60. doi: 10.1080/00074918.2017.1364349.

Ross, M. L. (2004). Does taxation lead to representation? British Journal of Political Science, 34(2), 229-249. doi: 10.1017/S0007123404000031

Sakurai, Y., \& Braithwaite, V. (2003). Taxpayers' perceptions of practitioners: Finding one who is effective and does the right thing? Journal of Business Ethics, 46(4), 375-387. doi: 10.1023/a:1025641518700.

Schmolders, G. (1959). Fiscal psychology: a new branch of public finance. National Tax Journal, $15,184-193$.

Schmolders, G. (1960). Das Irrationale in der o"ffentlichen Finanzwirtschaft. Suhrkamp: Frankfurt am Main.

Scholz, J. T., \& Pinney, N. (1995). Duty , Fear , and Tax Compliance : The Heuristic Basis of Citizenship Behavior. American Journal of Political Science, 39(2), 490-512. doi: 10.2307/2111622

Song, Y. D., \& Yarbrough, T. E. (1978). Tax ethics and taxpayer attitudes: A survey. Public Administration Review, 38(5), 442-452. doi:10.2307/975503.

Sumantry, D. (2011). Reformasi Perpajakan sebagai perlindungan hukum yang seimbang antara Wajib Pajak dengan Fiskus sebagai pelaksanaan terhadap Undang-undang Perpajakan. Jurnal Legislasi Indonesia, 8(1), 13-28.

Supriyadi, G., \& Guno, T. (2006). Budaya kerja organisasi pemerintah. Jakarta: Lembaga Administrasi Negara Republik Indonesia.

Susilawati, I. R., \& Hidayat, R. (2019a). Tax and Society: an exploratory study of fiscal psychology. In International Conference on Indigenous and Culture Psychology (ICICP)
Universitas Gadjah Mada. Yogyakarta

Susilawati, I. R., \& Hidayat, R. (2019b). Tax in the mind of the citizens: A social representation of tax. 2019. (dalam proses reviu Mediapsi).

Sutinen, J. G., \& Kuperan, K. (1999). A socio-economic theory of regulatory compliance. International Journal of Social Economics, 26(1-3), 174-193. doi: 10.1108/03068299910229569.

Tjakrawerdaja, S., Soedarno, S., Lenggono, P. S., Purwandaya, B., Karim, M., \& Agusalim, L. (2018). Sistem Ekonomi Pancasila. (M. Zaelani, Ed.) (Kedua). Depok: Rajawali Pers.

Torgler, B. (2007). Tax Compliance and Tax Morale. Massachussetts: Edward Elgar Publishing Limited. doi: 10.4337/9781847207203.

Torgler, B., \& Schneider, F. (2004). Does Culture Influence Tax Morale? Evidence from Different European Countries (Working Paper No. 2004 17 CREMA Gellertstrasse 24 CH - 4052 Basel www.crema-research.ch No. 24). Working Paper. Retrieved from http://www.cremaresearch.ch/papers/2004-17.pdf

Tyszka, T. (1994). Cognitive representation of economics. In IAREP/SABE Annual Colloquium. Amsterdam.

Wagner, W., Duveen, G., Farr, R., Jovchelovitch, S., Lorenzi-Cioldi, F., Markova, I., \& Rose, D. (1999). Theory and method of social representations. Asian Journal of Social Psychology, 2(1), 95-125. doi: 10.1111/1467-839X.00028.

Wenzel, M. (2005). Motivation or rationalisation? Causal relations between ethics, norms and tax compliance. Journal of Economic Psychology, 26(4),491-508.

doi: 10.1016/j.joep.2004.03.003.

Williamson, M. R., \& Wearing, A. J. (1996). Lay people's cognitive models of the economy. Journal of Economic Psychology, 17(1), 3-38. doi: 10.1016/0167-4870(95)00033-X. 